\title{
A euenantiornithine bird from the Late Cretaceous Haţeg Basin of Romania
}

Xia Wang, Gareth J. Dyke, Vlad Codrea, Pascal Godefroit, and Thierry Smith

Acta Palaeontologica Polonica 56 (4), 2011: 853-857 doi: http://dx.doi.org/10.4202/app.2010.0085

We present the first record of a euenantiornithine bird from Romania. A small collection of fossil remains from the Maastrichtian add to the known distribution of large euenantiornithines and descriptions of birds from the Haţeg Basin augment the known vertebrate fauna from this famous region of Transylvania. The new specimens referred here to an indeterminate taxon of euenantiornithine further demonstrate that the larger members of this diverse Cretaceous lineage were globally distributed, as many birds are today.

Xia Wang [xia.wang@ucdconnect.ie], School of Biology and Environmental Science, University College Dublin, Dublin, Ireland; Gareth J. Dyke [gareth.dyke@ucd.ie ], Ocean and Earth Science, Southampton University of Southampton,Southampton SO14 3ZH UK; Vlad Codrea [codrea vlad@yahoo.fr ], Universitatea Babes-Bolyai, Cluj-Napoca, Romania; Pascal Godefroit [Pascal.Godefroit@sciencesnaturelles.be], Thierry Smith [thierry.smith@ sciencesnaturelles.be ], Institut royal des sciences naturelles de Belgique, 29, rue Vautier, 1000 Bruxelles, Belgium.

This is an open-access article distributed under the terms of the Creative Commons Attribution License (for details please see creativecommons.org), which permits unrestricted use, distribution, and reproduction in any medium, provided the original author and source are credited. 